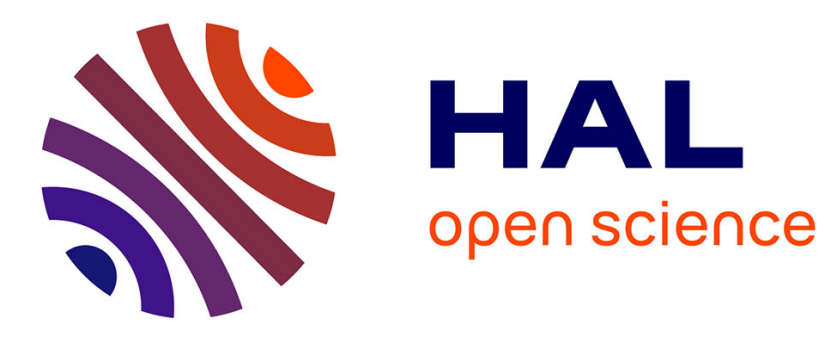

\title{
Conformational behavior, redox and spectroscopic properties of gold dithiolene complexes: [Au(iPr-thiazYdt)2]-1 (Y=O, S, Se)
}

Agathe Filatre-Furcate, Frédéric Barrière, Thierry Roisnel, Olivier Jeannin, Dominique Lorcy

\section{To cite this version:}

Agathe Filatre-Furcate, Frédéric Barrière, Thierry Roisnel, Olivier Jeannin, Dominique Lorcy. Conformational behavior, redox and spectroscopic properties of gold dithiolene complexes: $[\mathrm{Au}(\mathrm{iPr}-\mathrm{thiazYdt}) 2]-1 \quad(\mathrm{Y}=\mathrm{O}, \mathrm{S}, \mathrm{Se})$. Inorganica Chimica Acta, 2018, 469, pp.255-263. 10.1016/j.ica.2017.09.050 . hal-01619412

HAL Id: hal-01619412 https://hal-univ-rennes1.archives-ouvertes.fr/hal-01619412

Submitted on 13 Nov 2017

HAL is a multi-disciplinary open access archive for the deposit and dissemination of scientific research documents, whether they are published or not. The documents may come from teaching and research institutions in France or abroad, or from public or private research centers.
L'archive ouverte pluridisciplinaire HAL, est destinée au dépôt et à la diffusion de documents scientifiques de niveau recherche, publiés ou non, émanant des établissements d'enseignement et de recherche français ou étrangers, des laboratoires publics ou privés. 


\section{Conformational behavior, redox and spectroscopic properties of gold dithiolene complexes: $\left[\mathrm{Au}(i \mathrm{Pr}-\mathrm{thiazYdt})_{2}\right]^{-1}(\mathrm{Y}=\mathrm{O}, \mathrm{S}, \mathrm{Se})$}

Agathe Filatre-Furcate, Frédéric Barrière, Thierry Roisnel, Olivier Jeannin, Dominique Lorcy* Institut des Sciences Chimiques de Rennes, UMR 6226 CNRS-Université de Rennes 1, Campus de Beaulieu, Bât 10A, 35042 Rennes cedex, France.Email: dominique.lorcy@univ-rennes1.fr

\section{Abstract:}

Three monanionic gold dithiolene complexes with different exocyclic chalcogen atoms $(\mathrm{O}, \mathrm{S}$, Se) on the N-isopropyl-1,3-thiazoline-2-chalcogenone-4,5-dithiolate ligand, have been synthetized with the aim of modulating their properties. Due to the presence of the isopropyl ( $i$ Pr) group in the plane of the thiazoline-2-chalcogenone ring, different syn and anti rotamers can exist, in solution and in the solid state. Characterization of these complexes by spectroscopic and electrochemical methods was carried out in order to investigate the influence of the size, electronegativity and polarizability of the exocyclic chalcogen atom. The molecular structure of the three anionic complexes $\left[\mathrm{Au}(i \mathrm{Pr} \text {-thiazYdt })_{2}\right]^{-1}$, with $\mathrm{Y}=\mathrm{O}, \mathrm{S}$, Se, were established by single crystal X-ray diffraction studies. Theoretical calculations carried out at the DFT levels were realized on the three possible rotamers, syn/syn, syn/anti and antilanti of the trans-[Au(iPr-thiazYdt $\left.)_{2}\right]^{-1}$ complexes.

Keywords : dithiolene ligand; gold complex, rotamer, electrochemistry, X-ray diffraction

\section{Introduction}

When a molecule appears to be a promising precursor for the elaboration of conducting molecular materials, various chemical modifications of the precursor skeleton can be considered with the aim of a better understanding of the structure/property relationships. 
For instance, after the discovery of the first organic metal from the association of tetrathiafulvalene (TTF) and tetracyanoquinodimethane (TCNQ), numerous modifications of the TTF moiety have been performed, particularly by replacing two or four sulfur atoms by selenium atoms [1]. Neutral radical gold bis(dithiolene) complexes are also promising systems for the elaboration of single component molecular conductors [2,3] and, within this framework, we recently reported complexes noted $\left[\mathrm{Au}(\mathrm{R} \text {-thiazdt })_{2}\right]^{\bullet}(\mathrm{R}$-thiazdt : N-alkyl-1,3thiazoline-2-thione ring, Chart 1) where slight modifications performed on the dithiolene ligand skeleton play a crucial role in the observed properties [4,5].

\section{Chart 1}<smiles>[R]n1sc2c(sc3c1Sc1sc(=S)[se]c1S3)sc(=S)n2[R]</smiles>

[Au(R-thiazdt) $)_{2}$ ]

$\mathrm{R}=\mathrm{Et}, \mathrm{CH}_{2} \mathrm{CH}_{2} \mathrm{OH}, \mathrm{IPr}$

In the case of the isopropyl group on the nitrogen atom $(\mathrm{R}=i \operatorname{Pr})$, we noticed in the organic precursors as well as in the gold complexes, the existence of different rotamers due to the orientation of the $i \operatorname{Pr}$ group relative to the plane of the thiazoline-2-thione ring [5]. Indeed, two stable conformations can be envisaged with the hydrogen atom of the $i \operatorname{Pr}$ group in the plane of the heterocyclic ring oriented towards the thione group or towards the substituent located at the 4-position of the heterocycle. These isomers are respectively noted syn and anti rotamers and are depicted in Chart 2 for the protected dithiolene ligand. Roussel et al. demonstrated long range conformational effects on this conformational equilibrium between the syn and anti rotamers induced by the substituents in positions 4 and 5 of the 3 -isopropyl4-alkyl-thiazoline-2-thione derivatives [6,7]. Furthermore, the nature of the substituent at the 2-position of the heterocycle can also play a role [8]. 


\section{Chart 2}

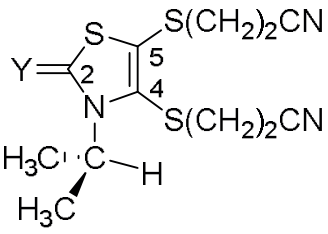

"syn"

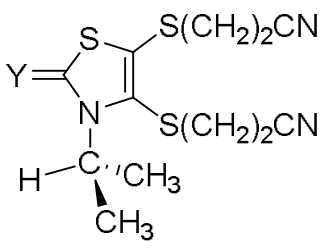

"anti"

$$
Y=O, S, S e
$$

Thus, we postulated that larger or smaller atoms such as selenium or oxygen at the 2-position of the thiazoline core could also induce some modification on this syn/anti equilibrium.

Moreover, within the chalcogen group, the increase of the atomic radius follows an increase of polarizability together with a decrease in electronegativity. Both criteria can modify the overall properties of the monanionic gold dithiolene species. Considering the importance of shape and size on the ability of a given complex to organize in the solid state in defined structures, we considered these modifications on the gold dithiolene complexes mentioned above and investigated accordingly the analogs of the monoanionic complex $[\mathrm{Au}(i \mathrm{Pr}-$ thiazdt $)_{2}$ ] by replacing the exocyclic sulfur atom in the 2-position by either oxygen or selenium atoms. In order to facilitate the distinction between the three derivatives, we used a different notation $\left[\mathrm{Au}(i \mathrm{Pr}-\mathrm{thiaz} \mathrm{Ydt})_{2}\right]$ with $\mathrm{Y}=\mathrm{O}, \mathrm{S}, \mathrm{Se}(\mathrm{Chart} 3)$.

\section{Chart 3}

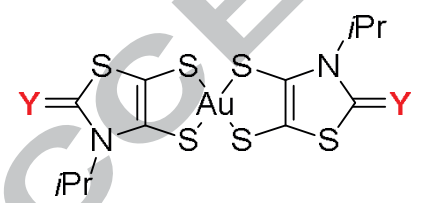

\section{[Au(Pr-thiazYdt) 2$]$} $Y=0, S$, Se

The preparation of the organic dithiolate ligand precursor as well as the corresponding anionic gold complexes will be described and the $i \operatorname{Pr}$ orientation will be investigated from a combination of variable temperature ${ }^{1} \mathrm{H}$ NMR, DFT calculations and X-ray crystal structure determinations. 


\section{Results and discussion}

2. 1. Synthesis and characterization of the proligands

The protected dithiolate ligands $\mathbf{2}, \mathbf{3}$ and $\mathbf{5}$, with respectively $\mathrm{Y}=\mathrm{S}, \mathrm{Se}, \mathrm{O}$, were prepared starting from thiazoline-2-thione 1 [9] according to the chemical pathway depicted in Scheme 1. The bis-metallation of $\mathbf{1}$ with LDA followed by the addition of $\mathrm{S}_{8}$ and bromopropionitrile led to 2 [5]. In order to generate the thiazoline-2-selone $\mathbf{3}$, the exocyclic sulfur atom of the thiazoline-2-thione $\mathbf{2}$ was first alkylated with methyl iodide in refluxing acetone. Reaction with sodium hydrogenoselenide afforded the protected dithiolate ligand $\mathbf{3}$ in $30 \%$ yield [10]. This strategy cannot be used for the preparation of the protected dithiolate ligand bearing a thiazoline-2-one core $(\mathrm{Y}=\mathrm{O})$. Indeed, the generation of a thiazoline-2-one from a thiomethyl salt implies the use of a basic reactant such as sodium methanolate which could also affect the cyanoethyl protecting group. Therefore, in order to avoid this unwanted deprotection, we performed the transformation into the thiazoline-2-one $\mathbf{4}$ on the unsubstituted $\mathrm{N}-i \operatorname{Pr}-1,3-$ thiazoline-2-thione 1. Its reaction with MeI in refluxing acetone affords the 2-methylthio-1,3thiazolium salt which subsequently treated by $\mathrm{NaOMe}$ leads to the corresponding $\mathrm{N}-i \mathrm{Pr}-1,3-$ thiazoline-2-thione 4 in $87 \%$ yield. Thus, the protected dithiolate ligand $\mathbf{5}$ is obtained by using the same operating conditions as those used to form $\mathbf{2}$.

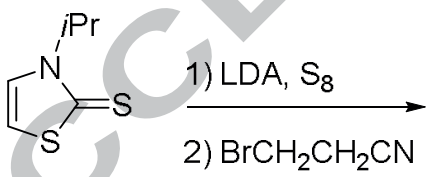

1<smiles>CCCn1c(SCCCN)c(SCCC#N)sc1=S</smiles>

2<smiles></smiles>

3

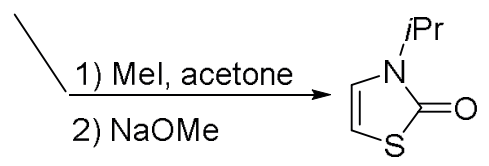

4
1) $L D A, S_{8}$

2) $\mathrm{BrCH}_{2} \mathrm{CH}_{2} \mathrm{CN}$<smiles>CC(C)n1c(SCCCN)c(SCCN)sc1=O</smiles>

5

Scheme 1. 
Interestingly, two different behaviors can be observed on the room temperature ${ }^{1} \mathrm{H}$ NMR spectra of the five thiazoline derivatives 1-5. For the precursors 1 and 4 which are not substituted on the 4 and 5 position of the thiazoline ring as well as for the protected dithiolate ligand $5(\mathrm{Y}=\mathrm{O})$, sharp signals are observed for the isopropyl group. Contrariwise, for the protected ligand $\mathbf{2}(\mathrm{Y}=\mathrm{S})$ and $\mathbf{3}(\mathrm{Y}=\mathrm{Se})$, broad signals for the isopropyl group are observed (Fig. 1). Thus, variable temperature ${ }^{1} \mathrm{H}$ NMR experiments were carried out on these two derivatives and the spectra recorded by decreasing the temperature by steps of $10 \mathrm{~K}$ are reported in Figure 1. Concerning the thiazoline-2-thione $\mathbf{2}$ which was previously reported [5], upon lowering the temperature, the broad signals decoalesce at $273 \mathrm{~K}$ into two doublets of approximatively equal intensity for the methyl group (1.83 and $1.69 \mathrm{ppm})$ and into two septuplets with a similar ratio 48:52 (5.30 and $5.96 \mathrm{ppm})$ indicating the presence of the two rotamers in equal proportion (Chart 1). Similar investigations carried out on the protected dithiolate ligand $\mathbf{3}$, with an exocyclic selenium atom, shows also a decoalescence of the signals observed at $273 \mathrm{~K}$, but with a slightly different evolution. Indeed, for $\mathbf{3}$ the signals decoalesce into two sets of signals corresponding to unequal rotamer populations (72:28). For instance, for the $\mathrm{C}-\mathrm{H}$ two septuplets at 5.98 and $5.40 \mathrm{ppm}$ with a ratio of $72: 28$ and for the methyl group two doublets at 1.66 and $1.88 \mathrm{ppm}$ with a ratio of 72:28 are observed. This indicates the presence of two rotamers in different proportions.
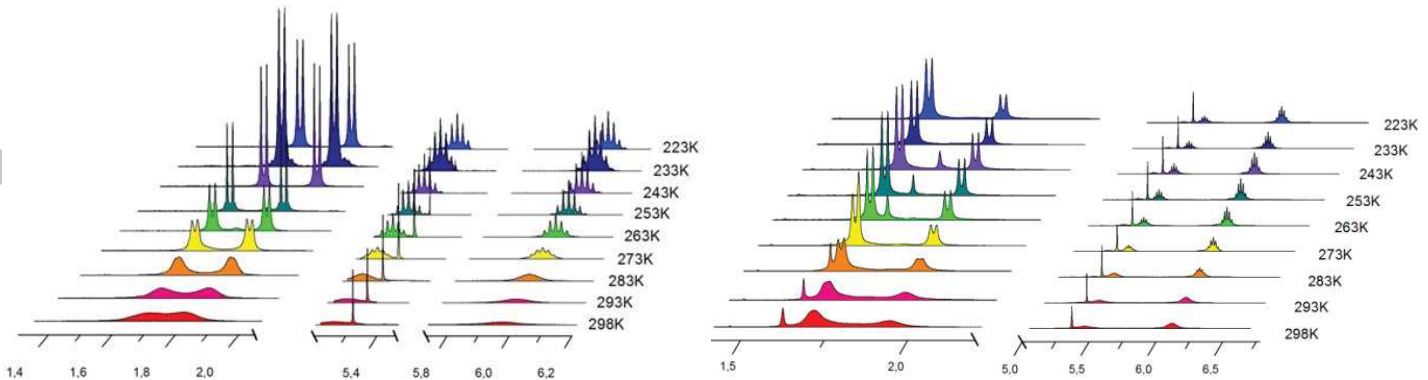

Fig. 1. ${ }^{1} \mathrm{H}$ NMR spectra of the isopropyl group, $\mathrm{C}-\mathrm{H}$ and $\mathrm{CH}_{3}$ protons, of $\mathbf{2}(\mathrm{Y}=\mathrm{S}$, left $)$ and $\mathbf{3}$ $(\mathrm{Y}=\mathrm{Se}$, right $)$ at various temperatures. 
In their work on thiazoline-2-thione analogues, Roussel and Sandström [11] attributed the signals observed for the $\mathrm{C}-\mathrm{H}$ at low field to the rotamer anti, due to the strong deshielding effect of the thiocarbonyl group. Accordingly, for $\mathbf{3}$ we assumed that the main isomer in solution was the rotamer anti (Chart 2). From this study, we also determined the free energy barriers between the syn and the anti forms which amounts to $14.5\left(60 \mathrm{~kJ}^{\mathrm{mol}}{ }^{-1}\right)$ and 15.8 kcal.mol ${ }^{-1}\left(66 \mathrm{~kJ}^{\mathrm{mol}}{ }^{-1}\right)$ for the proligands $2(\mathrm{Y}=\mathrm{S})$ and $\mathbf{3}(\mathrm{Y}=\mathrm{Se})$ respectively. This difference can be attributed to the size of the chalcogen atom at the 2 position of the thiazoline ring. Indeed, the larger energy barrier for $\mathbf{3}$ can be ascribed to the steric hindrance generated by the larger exocyclic selenium atom.

As mentioned above, the room temperature ${ }^{1} \mathrm{H}$ NMR spectrum of the protected form $\mathbf{5}$ with an exocyclic oxygen atom shows only one set of signals for the methyl and the $\mathrm{C}-\mathrm{H}$ groups. We also performed variable temperature experiments but this time by increasing the temperature by steps of $10 \mathrm{~K}$. Up to $333 \mathrm{~K}$ no difference can be observed on the spectra indicating that no coalescence occurs. Thus in this case, either only one rotamer exists, or the smaller size of the oxygen atom does not impede the free rotation of the isopropyl group.

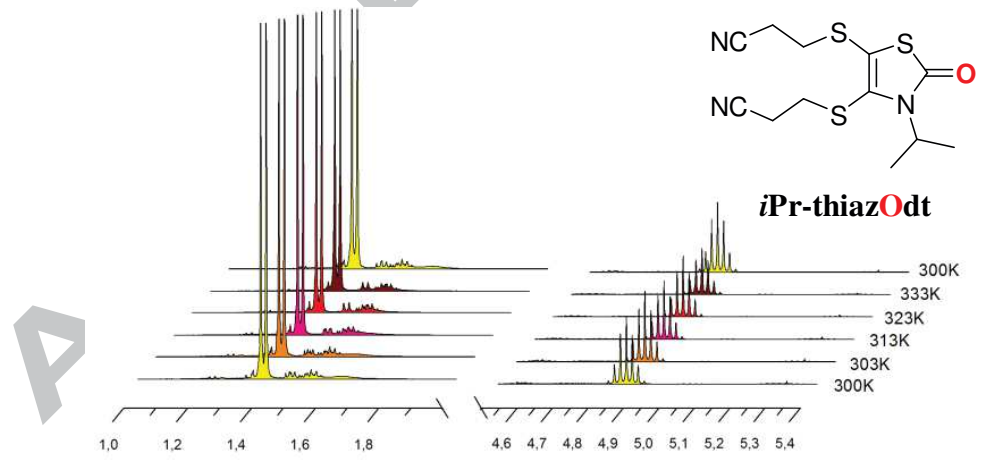

Fig. 2. ${ }^{1} \mathrm{H}$ NMR spectra of the isopropyl group, $\mathrm{C}-\mathrm{H}$ and $\mathrm{CH}_{3}$ protons, of $5(\mathrm{Y}=\mathrm{O})$ at various temperature. 
In order to discriminate between these hypotheses, geometry optimizations were carried out on the two rotamers, syn and anti, for each proligands 2,3 and 5 [DFT-B3LYP/6$31 \mathrm{G}^{*}$. In the three cases, the syn rotamer was found to have the lowest energy by 2.42 $\mathrm{kcal} / \mathrm{mol}$ for Se, $0.57 \mathrm{kcal} / \mathrm{mol}$ for S and by $2.60 \mathrm{kcal} / \mathrm{mol}$ for $\mathrm{O}$. These results indicate that the energy difference is more pronounced in the case of the proligands with either an exocyclic oxygen or selenium atom while for the sulfur derivative this difference is about four times smaller. This trend is in accordance with the experimental results obtained through the ${ }^{1} \mathrm{H}$ NMR investigations as for the sulfur derivatives upon lowering the temperature both rotamers were present in equal quantities while for the selenium one isomer is predominant (72\%) and for the oxygen atom only one isomer is observed. Thus these calculations are in favor of the presence of one rotamer for the oxygen derivative. This is in agrrement with the work of Sandström who observed that with N-iPr-1,3-thiazolin-2-one and large substituent at the 4-position, the conformer syn was favored [11].

Another interesting aspect is to compare the frontier molecular orbitals energy for these proligands. As shown in Table 1, the energy of the HOMO and the LUMO of the exocyclic sulfur derivative, either syn or anti rotamer, lies in between those of the exocyclic oxygen and selenium derivatives. The effect of the exocyclic atom on the energy difference between the HOMO and LUMO may be noted. Indeed, the $\Delta \mathrm{E}$ becomes smaller from the oxygen to the sulfur and selenium substitution. Accordingly a higher effect associated with electron delocalization is found with the selenium derivative.

Table $1 \mathrm{HOMO}$ and LUMO levels in $\mathrm{eV}$ of the different rotamers of the proligands

\begin{tabular}{lllllll}
\hline & O Syn & O Anti & S Syn & S Anti & Se Syn & Se Anti \\
\hline LUMO & -1.30 & -1.38 & -1.61 & -1.72 & -1.67 & -1.74 \\
HOMO & -6.178 & -6.183 & -5.83 & -5.89 & -5.50 & -5.57 \\
$\Delta \mathrm{E}$ & 4.878 & 4.803 & 4.22 & 4.17 & 3.83 & 3.83 \\
\hline
\end{tabular}




\subsection{Gold dithiolene complexes}

The synthesis of the gold dithiolene complexes derived from the proligands $\mathbf{2}, \mathbf{3}$ and $\mathbf{5}$ is depicted in Scheme 2. In order to prepare the monoanionic complexes, we first form the dithiolate ligand by adding sodium methanolate to a solution of the proligand. Addition of $\mathrm{KAuCl}_{4}$ and $\mathrm{PPh}_{4} \mathrm{Cl}$ to the medium yields the corresponding complexes (Scheme 2). Crystals of the three monoanionic gold complexes, $\left[\mathrm{Ph}_{4} \mathrm{P}\right]\left[\mathrm{Au}(i \mathrm{Pr}-\text { thiazYdt })_{2}\right], \mathrm{Y}=\mathrm{O}, \mathrm{S}$, Se, were obtained by slow concentration of acetonitrile solutions.

\section{Scheme 2}<smiles></smiles><smiles>COC(=O)OC</smiles>

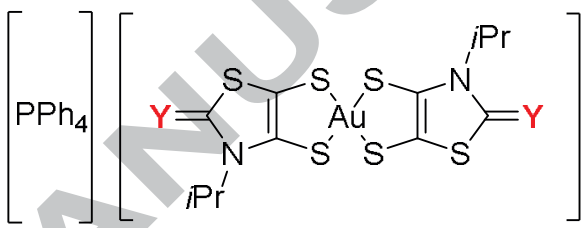

$2 \quad Y=S$

$3 \mathrm{Y}=\mathrm{Se}$

$5 \quad \mathrm{Y}=\mathrm{O}$

$$
\left[\mathrm{Ph}_{4} \mathrm{P}\right]\left[\mathrm{Au}(\mathrm{R}-\mathrm{thiaz} \mathrm{Ydt})_{2}\right] \quad \mathrm{Y}=\mathrm{O}, \mathrm{S}, \mathrm{Se}
$$

All three complexes are isostructural, they crystallize in the monoclinic system, space group $\mathrm{C} 2 / \mathrm{c}$ with the gold atom located on an inversion center. Selected bond distances and angles are collected in Table 2. The molecular structures of the monanionic gold bis(dithiolene) complexes are shown in Figure 3. The coordination geometry around the gold ion is square planar. Interestingly, despite the number of possible isomers, all these gold dithiolene complexes exhibit a trans configuration as mostly observed for gold dithiolene complexes obtained with disymmetrically substituted dithiolene ligand [4,12-14], with only few exceptions $[4 c, 15]$. Moreover, in the complexes with $\mathrm{Y}=\mathrm{S}$ and $\mathrm{Y}=\mathrm{Se}$, the rotamers syn/syn are observed in the solid state while for the complex with the exocyclic oxygen atoms, the $i \operatorname{Pr}$ substituent is disordered on two positions indicating that the syn and anti isomers are present in the solid state. The metallacycles are not fully planar and the folding angle along the S $\bullet \bullet$ S axis increases slightly with the heavier chalcogens O: $2.72(6)^{\circ}<\mathrm{S}: 5.13(7)^{\circ}<\mathrm{Se}$ : 
$6.61(12)^{\circ}$ (Table 2). This is in accordance with our previous observation on the N-Ethyl analogs $\left[\mathrm{Au}(\text { Et-thiazYdt })_{2}\right]^{-1}(\mathrm{Y}=\mathrm{O}, \mathrm{S})$ where this folding angle along the S$\bullet \bullet \mathrm{S}$ axis in the Et complex with $\mathrm{Y}=\mathrm{O}$ was significantly smaller than in the Et complex with $\mathrm{Y}=\mathrm{S}$ [4b].

(a)
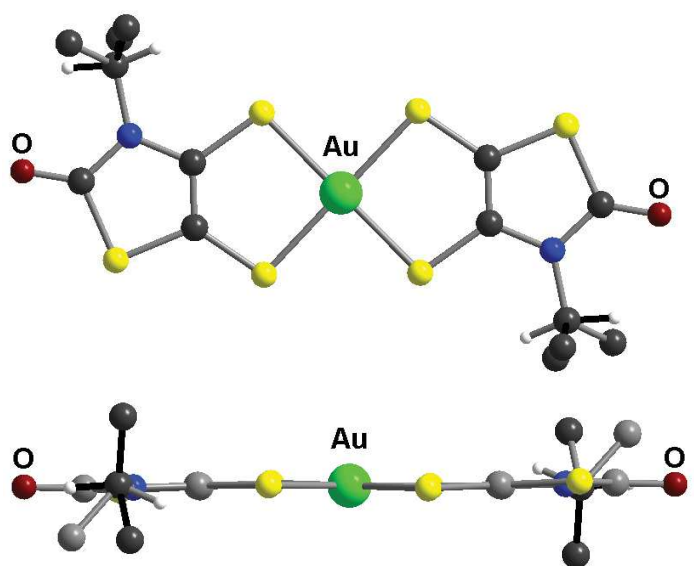

(b)

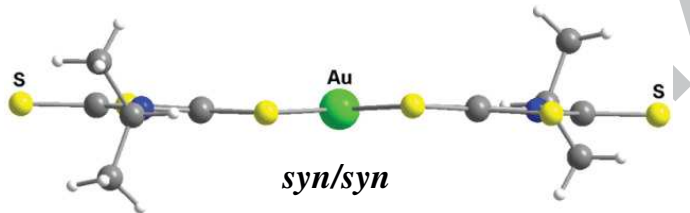

(c)

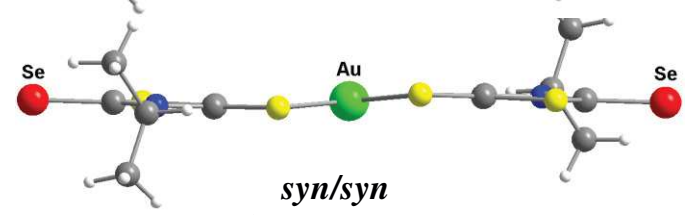

Fig. 3. Molecular structures of (a) $\left[\mathrm{Au}(i \mathrm{Pr}-\text { thiazOdt })_{2}\right]^{-1}$ apart de $\mathrm{C}-\mathrm{H}$ of the $i \mathrm{Pr}$ groups all the other hydrogen atoms have been omittted for clarity, (b) $\left[\mathrm{Au}(i \mathrm{Pr}-\mathrm{thiazSdt})_{2}\right]^{-1}$ et (c) $\left[\mathrm{Au}(i \mathrm{Pr} \text {-thiazSedt })_{2}\right]^{-1}$ in $\left[\mathrm{Ph}_{4} \mathrm{P}\right]\left[\mathrm{Au}(i \mathrm{Pr}-\text { thiazYdt })_{2}\right] \mathrm{Y}=\mathrm{O}, \mathrm{S}, \mathrm{Se}$

Comparison of the bond lengths of the three monoanionic gold complexes shows that the exocyclic chalcogen atom has indeed an influence on the bond lengths of the thiazoline moiety. These modifications can be ascribed to the difference of 
electronegativity/polarizability of the exocylic chalcogen atom which is significantly transmitted to the heterocycle. Despite these modifications, the bond lengths of the metallacycles are quite comparable for the three complexes. Comparison of bond angles of the thiazoline-2-chalcogenone core shows some differences associated with the nature of the chalcogen atom indicating the release of strain due to the size of the exocyclic atom (Table 3). This can be also viewed on the non-bonded distance between $\mathrm{S}_{1}$ and $\mathrm{C}_{3}(i \mathrm{Pr})$ which is the longest with the oxygen atom.

Table 2. Selected bond lengths $(\AA)$ and $\mathrm{S} \bullet \bullet \mathrm{S}$ angle, $\theta_{\mathrm{S} 1 \ldots \mathrm{S} 2}\left({ }^{\circ}\right)$ for $\left[\mathrm{PPh}_{4}\right]\left[\mathrm{Au}(i \mathrm{Pr}-\mathrm{thiazYdt})_{2}\right]$ $(\mathrm{Y}=\mathrm{O}, \mathrm{S}, \mathrm{Se})$.

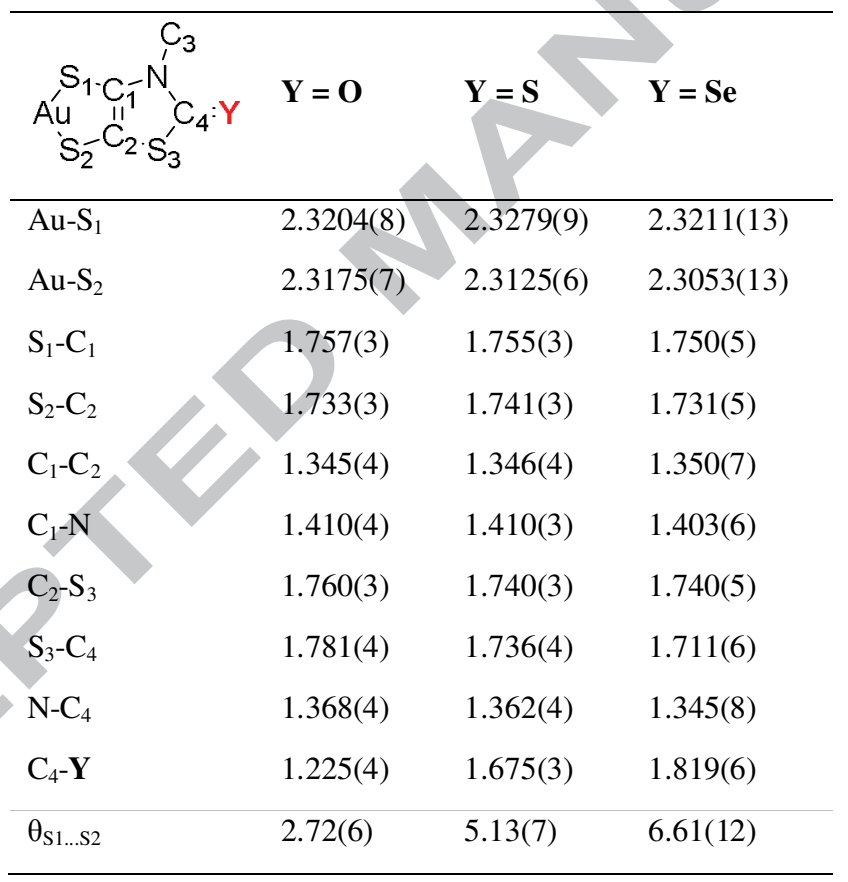


Table 3. Selected bond angles $\left(^{\circ}\right)$ and distances for the thiazoline core of $\left[\mathrm{Au}(i \mathrm{Pr}-\mathrm{thiazYdt})_{2}\right]^{-}$ ${ }^{1}(\mathrm{Y}=\mathrm{O}, \mathrm{S}, \mathrm{Se})$.

\begin{tabular}{|c|c|c|c|}
\hline 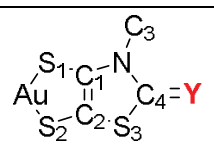 & $\mathbf{Y}=\mathbf{O}$ & $\mathbf{Y}=\mathbf{S}$ & $\mathbf{Y}=\mathbf{S e}$ \\
\hline $\mathrm{S}_{1}-\mathrm{Au}-\mathrm{S}_{2}$ & $92.08(3)$ & $92.12(2)$ & $92.15(5)$ \\
\hline $\mathrm{S}_{1}-\mathrm{C}_{1}-\mathrm{N}$ & 121.4(2) & $122.3(2)$ & $122.8(4)$ \\
\hline $\mathrm{C}_{1}-\mathrm{N}-\mathrm{C}_{3}$ & $124.6(3)$ & $120.5(2)$ & $120.4(5)$ \\
\hline $\mathrm{C}_{3}-\mathrm{N}-\mathrm{C}_{4}$ & $121.7(3)$ & $125.7(2)$ & $126.4(5)$ \\
\hline $\mathrm{N}-\mathrm{C}_{4}-\mathbf{Y}$ & 127.1(4) & $129.3(2)$ & $130.2(6)$ \\
\hline $\mathrm{Y}-\mathrm{C}_{4}-\mathrm{S}_{3}$ & $123.2(3)$ & $120.6(2)$ & $118.1(5)$ \\
\hline $\mathrm{S}_{3}-\mathrm{C}_{4}-\mathrm{N}$ & $109.7(3)$ & $110.1(2)$ & $111.6(5)$ \\
\hline $\mathrm{S}_{1} \ldots \mathrm{C}_{3}(\mathrm{iPr})$ & $3.181(4)$ & $3.120(4)$ & $3.121(10)$ \\
\hline $\mathbf{Y} \ldots \mathrm{C}_{3}(\mathrm{iPr})$ & $2.901(5)$ & $3.300(3)$ & $3.412(8)$ \\
\hline
\end{tabular}

As observed for the protected ligands 2,3 and $\mathbf{5}$ the ${ }^{1} \mathrm{H}$ NMR spectra of the complexes $\left[\mathrm{Au}(i \mathrm{Pr}-\mathrm{thiazYdt})_{2}\right]^{-1}(\mathrm{Y}=\mathrm{O}, \mathrm{S}, \mathrm{Se})$ recorded at room temperature show broad signals for the complexes with the two largest chalcogen atoms $(\mathrm{Y}=\mathrm{S}, \mathrm{Se})$ and a well-defined spectrum with $\mathrm{Y}=\mathrm{O}$. Actually, the ${ }^{1} \mathrm{H}$ NMR spectrum of $\left[\mathrm{Au}(i \mathrm{Pr} \text {-thiazOdt })_{2}\right]^{-1}$ displays two sharp doublets at 1.46 and $1.49 \mathrm{ppm}$ with a ratio of 55:45 assigned to the $\mathrm{CH}_{3}$ of the $i \operatorname{Pr}$ groups and a multiplet at $4.42 \mathrm{ppm}$ resulting from the superposition of two septuplets of almost equal intensity (Fig. 4). Due to the presence of dissymmetrical ligands, all these complexes are susceptible to adopt a trans and cis configuration in solution. Based on the observation performed on proligand $\mathbf{5}$, where we attributed the well-defined spectrum at room temperature to the presence of only one rotamer, the two sets of signals observed here at room temperature could be attributed to the coexistence of two diasteroisomers in solution, namely the cis and the trans isomers (chart 3). 


\section{Chart 3}<smiles>CC(C)n1c2c(sc1=O)S[Ge]1(Sc3sc(=O)n(C(C)C)c3S1)S2</smiles>

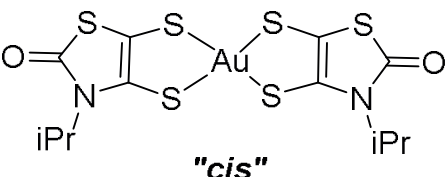

Contrariwise, for the two other complexes $\left[\mathrm{Au}(i \mathrm{Pr}-\mathrm{thiaz} \mathrm{Ydt})_{2}\right]^{-1}(\mathrm{Y}=\mathrm{S}, \mathrm{Se})$, two broad signals at 5.74 and $4.62 \mathrm{ppm}$ of unequal intensity were observed for the $\mathrm{C}-\mathrm{H}$ and a broad signal for the $\mathrm{CH}_{3}$ of the $i \operatorname{Pr}$ group. These broad signals indicate the existence of rotamers for these two complexes. For the $\mathrm{Y}=\mathrm{S}\left[\mathrm{Au}(i \mathrm{Pr}-\mathrm{thiazSdt})_{2}\right]^{-1}$ complex, it was previously shown that upon lowering the temperature, the two broad signals for the $\mathrm{C}-\mathrm{H}$ on the ${ }^{1} \mathrm{H}$ NMR spectra, with a ratio of 92:8 (5.74 and $4.62 \mathrm{ppm})$ decoalesce into two sharp multiplets resulting from the superposition of two septuplets due to the presence of possible six isomers in solution [5]. Variable temperature ${ }^{1} \mathrm{H}$ NMR experiments carried out on the $\mathrm{Y}=\mathrm{Se}[\mathrm{Au}(i \mathrm{Pr}-$ thiazSedt $\left.)_{2}\right]^{-1}$ complex show one broad signal at $5.7 \mathrm{ppm}$ for the $\mathrm{C}-\mathrm{H}$ in favor of one rotamer in solution (Fig. 4). Upon lowering the temperature, one sharp septuplet is observed, indicating that in this case no cis/trans isomerism is observed.
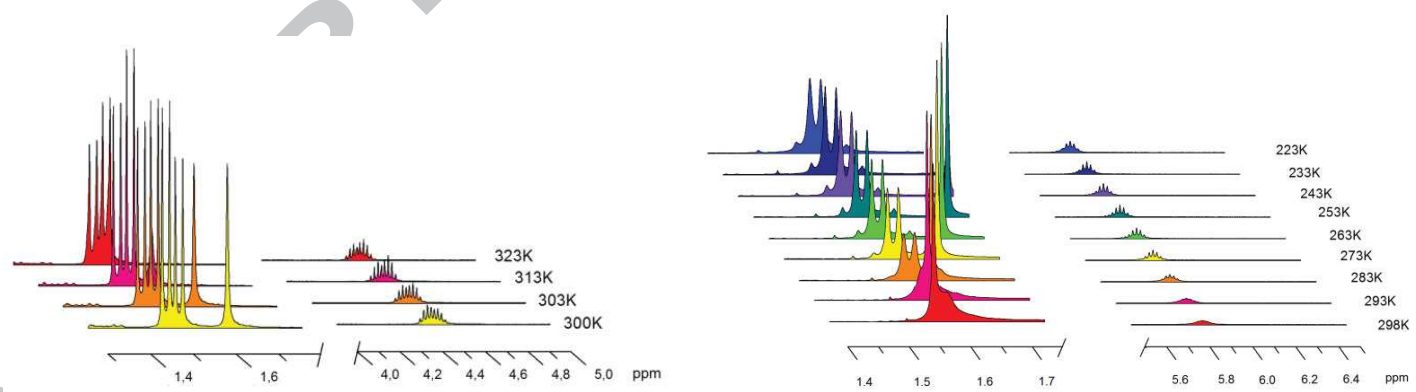

Fig. 4. ${ }^{1} \mathrm{H}$ NMR spectra of the $i \mathrm{Pr}$ group, $\mathrm{C}-\mathrm{H}$ and $\mathrm{CH}_{3}$ protons, of $\left[\mathrm{Au}(i \mathrm{Pr}-\text { thiazOdt })_{2}\right]^{-1}$ (left) and $\left[\mathrm{Au}(i \mathrm{Pr} \text {-thiazSedt })_{2}\right]^{-1}$ (right) at various temperature. 
Redox properties Gold bis(dithiolene) complexes are electroactive species. To determine the redox behavior of $\left[\mathrm{Au}(\mathrm{iPr}-\mathrm{thiaz} \mathrm{Ydt})_{2}\right]^{-1}(\mathrm{Y}=\mathrm{O}, \mathrm{S}, \mathrm{Se})$ species, we carried out cyclic voltammetry investigations, in dichloromethane in the presence of $\mathrm{NBu}_{4} \mathrm{PF}_{6} 0.1 \mathrm{M}$ as supporting electrolyte. The redox potentials are given in V vs SCE and are collected in Table 4 together with those of those of the N-Ethyl analogues $\left[\mathrm{Au}(\text { Et-thiazYdt })_{2}\right]^{-1}$ for comparison purposes $(Y=O, S)[4 b]$. Three different cyclic voltammograms $(\mathrm{CV})$ were obtained as shown in Figure 5. For $\left[\mathrm{Au}\left(\mathrm{iPr}-\mathrm{thiaz} \mathrm{Ydt}_{2}\right]^{-1}(\mathrm{Y}=\mathrm{O}, \mathrm{S})\right.$, upon anodic scan two oxidation processes are observed corresponding to the reversible oxidation of the monoanionic species into the neutral one and to the monacationic species. Surprisingly, the presence of exocyclic electronegative oxygen atoms increases the overall donating ability of the complex as the first oxidation potential of $\left[\mathrm{Au}(\mathrm{iPr}-\mathrm{thiazOdt})_{2}\right]^{-1}$ occurs at $0.38 \mathrm{~V}$ while it is at $0.52 \mathrm{~V}$ for $[\mathrm{Au}(\mathrm{iPr}-$ thiazSdt $\left.)_{2}\right]^{-1}$. Interestingly, the nature of the exocyclic atom influences also the potential domain of stability of the neutral species. Indeed the potential difference $(\Delta \mathrm{E})$ between the first and the second oxidation potential for $\mathrm{Y}=\mathrm{O}$ amounts to $470 \mathrm{mV}$ while for $\mathrm{Y}=\mathrm{S}$ it is much smaller $(110 \mathrm{mV})$. On the other hand, for $\mathrm{Y}=\mathrm{S}$ and $\mathrm{Y}=\mathrm{Se}$ the heteroatom does not modify significantly the first oxidation potential. On the $\mathrm{CV}$ of $\left[\mathrm{PPh}_{4}\right]\left[\mathrm{Au}(i \mathrm{Pr} \text {-thiazSedt })_{2}\right]$ the redox processes are poorly defined due to adsorption phenomena at the electrode.
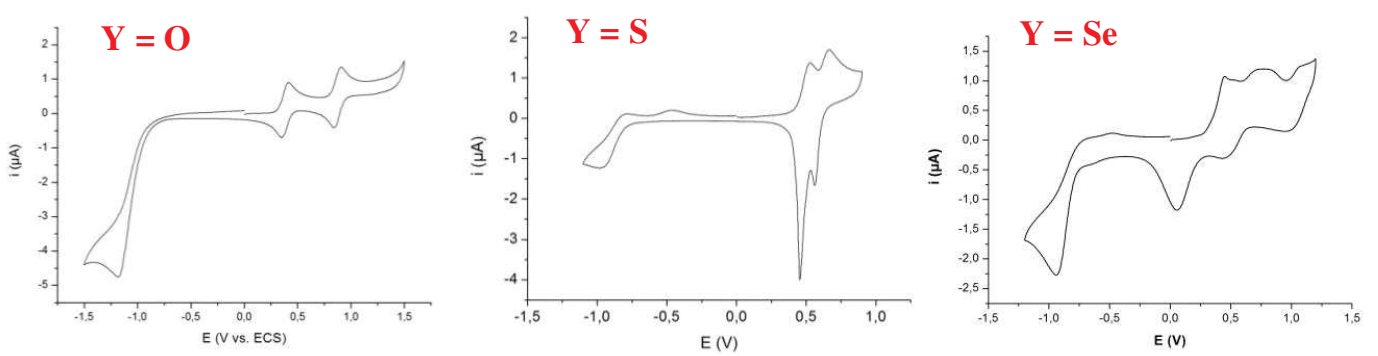

Fig. 5. Cyclic volatommgrams of $\left[\mathrm{PPh}_{4}\right]\left[\mathrm{Au}(i \mathrm{Pr}-\text { thiazOdt })_{2}\right]($ left $),\left[\mathrm{PPh}_{4}\right]\left[\mathrm{Au}(i \mathrm{Pr}-\text { thiazSdt })_{2}\right]$ (middle), [PPh $]\left[\mathrm{Au}\left(i \mathrm{Pr}\right.\right.$-thiazSedt) 2 (right) in $\mathrm{CH}_{2} \mathrm{Cl}_{2}, 0.1 \mathrm{M} \mathrm{NBu}_{4} \mathrm{PF}_{6}, \mathrm{Pt}, \mathrm{SCE}$, $100 \mathrm{mV} \cdot \mathrm{s}^{-1}$. 
If we compare the redox potentials of the complexes bearing an ethyl or an isopropyl substitutent on the nitrogen with the same outer chalcogen atom no modifications are observed. All these complexes exhibit on the cathodic scan an irreversible process attributed to the reduction of the monoanionic species into the dianionic complex. There again the nature of the outer chalcogen atom modifies the ease of reducing the complex and is consistent with the anodic behavior. The presence of the selenium atom facilitates the reduction while that of oxygen makes it more difficult. At first sight, the redox behavior of these complexes is in contrast with what would be expected if one considers only the electronegativity influence of the chalcogen atoms. However, this trend has also been noted on nickel dithiolene complexes $\left(\mathrm{Bu}_{4} \mathrm{~N}\right)_{2}\left[\mathrm{Ni}(\mathrm{dmit})_{2}\right]$ and $\left(\mathrm{Bu}_{4} \mathrm{~N}\right)_{2}\left[\mathrm{Ni}(\mathrm{dmid})_{2}\right](\mathrm{dmit}=2$-thioxo1,3-dithiole-4,5-dithiolate and dmid = 2-oxo-1,3-dithiole-4,5-dithiolate) $[16,17]$.

Table 4. Redox potentials of gold complexes $\left[\mathrm{PPh}_{4}\right]\left[\mathrm{Au}(\mathrm{R}-\mathrm{thiaYdt})_{2}\right](\mathrm{Y}=\mathrm{O}, \mathrm{S}, \mathrm{Se}), \mathrm{E}$ in $\mathrm{V}$ vs. $\mathrm{SCE}, \mathrm{CH}_{2} \mathrm{Cl}_{2}, \mathrm{NBu}_{4} \mathrm{PF}_{6}, \mathrm{Pt}, 100 \mathrm{mV} . \mathrm{s}^{-1}$.

\begin{tabular}{|c|c|c|c|c|c|c|}
\hline $\mathrm{R}$ & $\mathrm{Y}$ & $\mathbf{E}_{\mathrm{red}}^{*}$ & $E_{1}^{-1 / 0}$ & $\mathbf{E}_{2}{ }^{0 /+1}$ & $\Delta \mathbf{E}(\mathbf{m V})$ & $\lambda[\mathrm{nm}]\left(\varepsilon\left[\mathbf{M}^{-1} \cdot \mathrm{cm}^{-1}\right]\right)$ \\
\hline$i \operatorname{Pr}$ & $\mathrm{O}$ & -1.16 & 0.38 & 0.86 & 480 & 290 (33500), 260 (49500), 232 (70950) \\
\hline$i \operatorname{Pr}$ & S & -0.95 & 0.52 & 0.63 & 110 & $\begin{array}{l}366(21100), 296(18000), 262(23800) \\
232(40400)\end{array}$ \\
\hline$i \operatorname{Pr}$ & $\mathrm{Se}$ & -0.92 & $0.50^{*}$ & $0.75^{*}$ & & $390(33650), 262(24600), 232(46400)$ \\
\hline Et & $\mathrm{O}$ & -1.05 & 0.39 & 0.86 & 470 & \\
\hline Et & S & -0.90 & 0.52 & 0.65 & 130 & \\
\hline
\end{tabular}


Absorption UV-vis-NIR spectroscopy: UV-vis-NIR investigations have been carried out on these complexes solubilized in dichloromethane $\left(\mathrm{C}=1.710^{-5} \mathrm{M}\right)$. These complexes exhibit aborption bands in the UV-vis region only and the data are gathered in Table 4. The absorption spectra of the three complexes display some similarities in the region 200-330 nm but with a main difference concerning the lowest energy absorption band (Fig. 6). Similar spectra have been obtained with other monanionic gold complexes $[18,19]$. On the spectra, it can be observed a significant influence of the outer chalcogen atom on the optical properties of the complexes especially on the absorption band observed at the lower energies. For instance, the value of this absorption band varies from $290 \mathrm{~nm}$ for the complex with oxygen atoms, to $360 \mathrm{~nm}$ for the one with sulfur atoms to reach $390 \mathrm{~nm}$ for the one with selenium atoms. Thus from the oxygen to the sulfur and the selenium atom the electronic delocalization on the ligand is increased. Attempts to analyze these complexes through spectroelectrochemical experiments were unsuccessful due to the adsorption of the neutral species at the electrode.

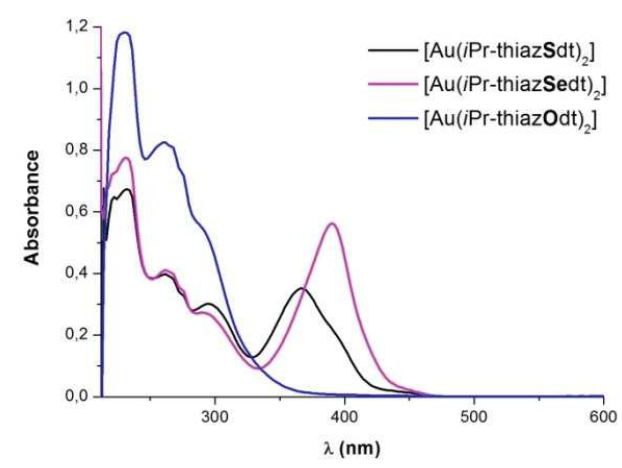

Fig. 6. UV-Vis spectra of $\left[\mathrm{PPh}_{4}\right]\left[\mathrm{Au}(i \mathrm{Pr}-\text { thiazYdt })_{2}\right](\mathrm{Y}=\mathrm{O}, \mathrm{S}, \mathrm{Se})$ in $\mathrm{CH}_{2} \mathrm{Cl}_{2}$.

In order to better understand their structural, electrochemical and spectroscopic characteristics, density functional theoretical (DFT) calculations have been carried out on 
these three complexes. They all can exist under the cis and trans configuration due to the presence of the dissymmetrical ligand, but since all the structures determined by X-ray crystallography are under the trans configuration, these calculations were performed only on the trans isomers. Geometry optimizations were carried out on the three possible rotamers for each trans-[Au(iPr-thiazYdt $\left.)_{2}\right]^{-1}$ complexes $(\mathrm{Y}=\mathrm{O}, \mathrm{S}, \mathrm{Se})$ using DFT calculations at the B3LYP/LanL2DZ level. All the optimized structures display a planar geometry around the gold atom unlike what was observed on the molecular structure determined by X-ray diffraction analysis. As an example, the optimized molecular structures of the three rotamers of the $\mathrm{Y}=\mathrm{O}$ trans- $\left[\mathrm{Au}(\mathrm{iPr}-\text { thiazOdt })_{2}\right]^{-1}$ complex are represented in Figure 7.

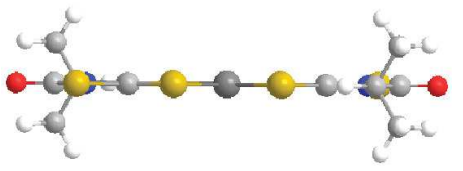

$\operatorname{syn} / s y n$

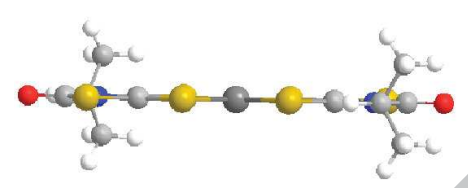

anti/syn

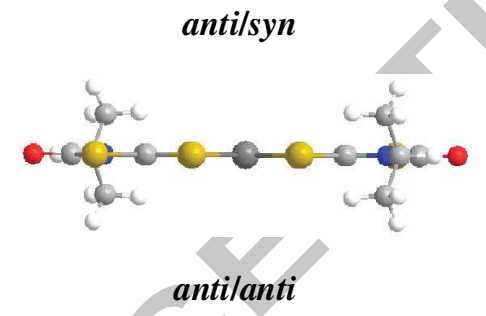

Fig. 7 Optimized geometry for the 3 possible rotamers, syn/syn, anti/syn and antilanti, calculated for the trans-[Au(iPr-thiazOdt $\left.)_{2}\right]^{-1}$ complex at the B3LYP/LanL2DZ level.

In the case of the trans-[Au(iPr-thiazOdt $\left.)_{2}\right]^{-1}$ complex, the most stable rotamer is the syn/syn rotamer. This rotamer is more stable than the anti/syn by $1.10 \mathrm{kcal} / \mathrm{mol}$ while the antilanti is disfavored by $2.21 \mathrm{kcal} / \mathrm{mol}$ compared to the syn/syn. For the two other complexes, namely trans- $\left[\mathrm{Au}(i \mathrm{Pr}-\text { thiazSdt })_{2}\right]^{-1}$ and trans-[Au(iPr-thiazSedt$\left.)_{2}\right]^{-1}$, the most stable rotamer is the 
antilanti conformer. The small energy difference between the most stable conformer, antilanti, and the syn/anti one reaches 0.67 and $1.19 \mathrm{kcal} / \mathrm{mol}$ for the sulfur and the selenium complexes while it attains for the syn/syn $1.35 \mathrm{kcal} / \mathrm{mol}$ and $2.40 \mathrm{kcal} / \mathrm{mol}$ for the sulfur and the selenium complexes respectively. As observed for the proligand $2(\mathrm{Y}=\mathrm{S})$ the energy difference between the global minimum and the highest energy in trans-[Au(iPr-thiazSdt $\left.)_{2}\right]^{-1}$ complex is the smallest found in the series. A plausible interpretation for these observations would be that the thiocarbonyl and the sulfur alkyl chain at the 4-position exhibit a relatively close steric hindrance. It is worth noting that it does not correspond to the experimentally obtained structures from single X-ray diffraction analysis for both complexes trans-[Au( $i \mathrm{Pr}$ thiazYdt $\left.)_{2}\right]^{-1}(\mathrm{Y}=\mathrm{S}, \mathrm{Se})$. Actually, the presence of the tetraphenylphosphonium counter ion and solvent effects may contribute to this discrepancy between theoretical and experimental results.

Table 5 HOMO and LUMO levels in eV of the different rotamers of the trans-[Au( $i \mathrm{Pr}-$ thiazYdt $\left.)_{2}\right]^{-1}$ complexes $(\mathrm{Y}=\mathrm{O}, \mathrm{S}, \mathrm{Se})$

\begin{tabular}{|c|c|c|c|c|c|c|c|c|c|}
\hline & \multicolumn{3}{|c|}{ trans $-\left[\mathrm{Au}(i \mathrm{Pr}-\text { thiazOdt })_{2}\right]^{-1}$} & \multicolumn{3}{|c|}{ trans $-\left[\mathrm{Au}(i \mathrm{Pr}-\mathrm{thiazSdt})_{2}\right]^{-1}$} & \multicolumn{3}{|c|}{ trans $-\left[\mathrm{Au}(i \mathrm{Pr} \text {-thiazSedt })_{2}\right]^{-1}$} \\
\hline & syn/syn & antilsyn & antilanti & syn/syn & anti/syn & antilanti & syn/syn & anti/syn & antilanti \\
\hline & & & & & -1.36 & & & -1.44 & -1.38 \\
\hline & & -2.36 & -2.36 & & -2.60 & -2.59 & -2.60 & -2.61 & -2.59 \\
\hline$\Delta \mathrm{E}$ & 1.26 & 1.29 & 1.31 & 1.22 & 1.24 & 1.26 & 1.19 & 1.17 & 1.21 \\
\hline
\end{tabular}

The calculated HOMO-LUMO gap, $\Delta \mathrm{E}$ (Table 5) for the three trans-rotamers of the complexes follows the same trend as the one observed for the proligands above, that is the $\Delta \mathrm{E}$ for the trans-[Au(iPr-thiazSedt $\left.)_{2}\right]^{-1}$ is the smallest one and the $\Delta \mathrm{E}$ for the trans- $[\mathrm{Au}(i \mathrm{Pr}-$ thiazOdt $\left.)_{2}\right]^{-1}$ is the highest one in accordance with UV-vis spectroscopic investigations. The shift to higher energies of the HOMO and the LUMO for the trans-[Au(iPr-thiazOdt $\left.)_{2}\right]^{-1}$ complex compared to the sulfur and selenium analogs is in agreement with the 
electrochemical investigations and the observed easier oxidation of this complex as well as the observed more difficult reduction of this complex.

\section{Conclusions}

In summary, a series of monoanionic gold dithiolene complexes with $i \operatorname{Pr}$ groups on the thiazole core of the ligand and with different exocyclic chalcogen atoms, $\left[\mathrm{Au}(\mathrm{iPr} \text {-thiazYdt })_{2}\right]^{-1}$ $(\mathrm{Y}=\mathrm{O}, \mathrm{S}, \mathrm{Se})$ has been synthetized and studied. A combination of electrochemical, spectroscopic and structural data together with theoretical calculations have evidenced the influence of the nature of the outer chalcogen atom $(\mathrm{O}, \mathrm{S}, \mathrm{Se})$ on the spectroscopic and redox properties of these complexes. Particularly, compared to sulfur and selenium, the exocyclic oxygen atom increases the potential domain of stability of the neutral radical species. Moreover the relative size of these chalcogen atoms and the steric hindrance generated influence the conformational equilibrium between the two preferred orientation of the $i \operatorname{Pr}$ against the thiazoline-2-chalcogenone ring, namely the syn and trans one. This study highlights how a simple change can tune the different properties of these gold dithiolene complexes.

\section{Experimental Section}

4.1. Materials and general methods

NMR spectra were recorded at room temperature using $\mathrm{CDCl}_{3}$ unless otherwise noted.

Chemical shifts are reported in ppm and ${ }^{1} \mathrm{H}$ NMR spectra were referenced to residual $\mathrm{CHCl}_{3}$ (7.26 ppm) and ${ }^{13} \mathrm{C}$ NMR spectra were referenced to $\mathrm{CHCl}_{3}$ (77.2 ppm). Melting points were measured on a Kofler hot-stage apparatus and are uncorrected. Mass spectra were recorded 
with Waters Q-Tof 2 instrument by the Centre Régional de Mesures Physiques de l'Ouest, Rennes. Elemental analyses were performed at the Centre Régional de Mesures Physiques de l'Ouest, Rennes. Column chromatography was performed using silica gel Merck 60 (70-260 mesh). CVs were carried out on a $10^{-3} \mathrm{M}$ solution of complex in $\mathrm{CH}_{2} \mathrm{Cl}_{2}-\left[\mathrm{NBu}_{4}\right]\left[\mathrm{PF}_{6}\right] 0.1 \mathrm{M}$. Potentials were measured versus Saturated Calomel Electrode (SCE). Chemicals and materials from commercial sources were used without further purification.

\subsection{Synthesis and characterization}

\section{Bis(4,5-cyanoethylthio)-1,3-thiazoline-2-selone 3.}

Under inert atmosphere, 1,3-thiazoline $2(2.34 \mathrm{mmol}, 0.77 \mathrm{~g})$ was dissolved in $15 \mathrm{~mL}$ of anhydrous acetonitrile. After the addition of iodomethane $(2.92 \mathrm{mmol}, 0.2 \mathrm{~mL})$ the reaction mixture was stirred for 24 hours, under argon atmosphere, at $50^{\circ} \mathrm{C}$. The medium was cooled at $0^{\circ} \mathrm{C}$ and acetonitrile was evaporated. The orange oil was used for the next reactions without other purification. ${ }^{1} \mathrm{H}$ NMR $(300 \mathrm{MHz}) \delta 1.64\left(\mathrm{~d}, 6 \mathrm{H}, \mathrm{CH}_{3},{ }^{3} \mathrm{~J}_{\mathrm{HH}}=7.5 \mathrm{~Hz}\right), 2.1\left(\mathrm{~s}, 3 \mathrm{H}, \mathrm{CH}_{3}\right)$, $2.68\left(\mathrm{t}, 4 \mathrm{H}, \mathrm{CH}_{2},{ }^{3} \mathrm{~J}_{\mathrm{HH}}=7.0 \mathrm{~Hz}\right), 3.04\left(\mathrm{t}, 4 \mathrm{H}, \mathrm{CH}_{2},{ }^{3} \mathrm{~J}_{\mathrm{HH}}=7.0 \mathrm{~Hz}\right), 3.42\left(\mathrm{t}, 2 \mathrm{H}, \mathrm{CH}_{2},{ }^{3} \mathrm{~J}_{\mathrm{HH}}=7.5\right.$ Hz), 4.8 (sept, 1H). Under inert atmosphere, sodium borohydride (0.19 g, $5.28 \mathrm{mmol})$ was dissolved in $20 \mathrm{ml}$ of absolute ethanol. Selenium powder ( $4.68 \mathrm{mmol}, 0.37 \mathrm{~g})$ was added to the solution. The reaction medium was stirred until the formation of a homogeneous solution and the thiazolium salt $(2.34 \mathrm{mmol})$ dissolved in $8 \mathrm{ml}$ of anhydrous acetonitrile was added. After stirring 30 minutes, the solution was added to a $10 \%$ acetic acid solution. Ethanol and acetonitrile were evaporated and the medium was extracted with dichloromethane. The organic phase was washed with water and dried over $\mathrm{MgSO}_{4}$. The resulting oil was purified by column chromatography on silica gel using $\mathrm{CH}_{2} \mathrm{Cl}_{2} / \mathrm{Et}_{2} \mathrm{O}(9.7 / 0.3)$ as eluent to afford the thiazoline-2-selone 3 as a yellow oil in $30 \%$ yield. $\mathrm{R}_{f}=0.63\left(\mathrm{SiO}_{2}, \mathrm{CH}_{2} \mathrm{Cl}_{2} / \mathrm{Et}_{2} \mathrm{O}, 9.7 / 0.3\right) .{ }^{1} \mathrm{H}$

NMR (300 MHz) $\delta$ rotamer anti $(72 \%): 1.66\left(\mathrm{~d}, 6 \mathrm{H}, \mathrm{CH}_{3},{ }^{3} \mathrm{~J}_{\mathrm{HH}}=7.1 \mathrm{~Hz}\right), 2.84\left(\mathrm{t}, 4 \mathrm{H}, \mathrm{CH}_{2}\right.$, 
$\left.{ }^{3} \mathrm{~J}_{\mathrm{HH}}=7.1 \mathrm{~Hz}\right), 2.78\left(\mathrm{t}, 4 \mathrm{H}, \mathrm{CH}_{2},{ }^{3} \mathrm{~J}_{\mathrm{HH}}=7.1 \mathrm{~Hz}\right), 5.98\left(\right.$ sept $\left., 1 \mathrm{H}, \mathrm{CH},{ }^{3} \mathrm{~J}_{\mathrm{HH}}=7.1 \mathrm{~Hz}\right)$; rotamer $\operatorname{syn}(28 \%): 1.88\left(\mathrm{~d}, 6 \mathrm{H}, \mathrm{CH}_{3},{ }^{3} \mathrm{~J}_{\mathrm{HH}}=7.0 \mathrm{~Hz}\right), 3.15\left(\mathrm{t}, 4 \mathrm{H}, \mathrm{CH}_{2},{ }^{3} \mathrm{~J}_{\mathrm{HH}}=7.0 \mathrm{~Hz}\right), 3.25(\mathrm{t}, 4 \mathrm{H}$, $\left.\mathrm{CH}_{2},{ }^{3} \mathrm{~J}_{\mathrm{HH}}=7.0 \mathrm{~Hz}\right), 5.40\left(\mathrm{sept}, 1 \mathrm{H}, \mathrm{CH},{ }^{3} \mathrm{~J}_{\mathrm{HH}}=7.0 \mathrm{~Hz}\right) \cdot{ }^{13} \mathrm{C}$ NMR $(75 \mathrm{MHz}) \delta$ : rotamer anti: $18.5\left(\mathrm{~N}-\mathrm{CH}\left(\underline{\mathrm{CH}}_{3}\right)_{2}\right), 18.7\left(\mathrm{~S}-\mathrm{CH}_{2}-\underline{\mathrm{C}} \mathrm{H}_{2}-\mathrm{CN}\right), 31.2\left(\mathrm{~S}-\underline{\mathrm{CH}}_{2}-\mathrm{CH}_{2}-\mathrm{CN}\right), 53.2(\mathrm{CH}), 118.1(\mathrm{CN})$, 126.2 (=C), 135.5 (=C), $186.9(\mathrm{C}=\mathrm{Se})$; rotamer syn: $20.7\left(\mathrm{~N}-\mathrm{CH}\left(\underline{\mathrm{CH}}_{3}\right)_{2}\right), 19.0\left(\mathrm{~S}_{-}-\mathrm{CH}_{2}-\underline{\mathrm{CH}}_{2}-\right.$ $\mathrm{CN}), 33.3\left(\mathrm{~S}-\mathrm{CH}_{2}-\mathrm{CH}_{2}-\mathrm{CN}\right), 56.8(\mathrm{CH}), 118.2(\mathrm{CN}), 128.9(=\mathrm{C}), 136.8(=\mathrm{C}), 187.7(\mathrm{C}=\mathrm{Se})$. HRMS (ASAP, QTOF 2) calcd for $\mathrm{C}_{12} \mathrm{H}_{16} \mathrm{~N}_{3} \mathrm{~S}_{3} \mathrm{Se}^{+}$: 377.96716, found: 377.9668 .

\section{N-iPr-1,3-thiazoline-2-one 4}

To a solution of 1,3-thiazoline-2-thione $\mathbf{1}(2 \mathrm{~g}, 12.6 \mathrm{mmol})$ in dry acetone $(15 \mathrm{~mL})$ was slowly added iodomethane $(1.0 \mathrm{~mL}, 15.1 \mathrm{mmol})$. The reaction was stirred at room temperature for 2 $\mathrm{h}$ under inert atmosphere. The medium was cooled to $0{ }^{\circ} \mathrm{C}$ and the precipitate was filtered and washed with a minimum amount of cold acetone. The 2-thiomethyl-1,3-thiazolium salt was dried under vacuum. The thiazolium salt was obtained in quantitative yield $(3.8 \mathrm{~g}) ; \mathrm{mp}=176$ ${ }^{\circ} \mathrm{C} .{ }^{1} \mathrm{H}$ NMR $(300 \mathrm{MHz}) \delta: 1.72\left(\mathrm{~d}, 6 \mathrm{H}, \mathrm{CH}_{3},{ }^{3} \mathrm{~J}_{\mathrm{HH}}=7.4 \mathrm{~Hz}\right), 3.06\left(\mathrm{~s}, 3 \mathrm{H}, \mathrm{SCH}_{3}\right), 4.77$ (sept, $\left.1 \mathrm{H}, \mathrm{CH},{ }^{3} \mathrm{~J}_{\mathrm{HH}}=7.5 \mathrm{~Hz}\right), 8.40\left(\mathrm{~d}, 1 \mathrm{H}, \mathrm{CH}^{3} \mathrm{~J}_{\mathrm{HH}}=6.9 \mathrm{~Hz}\right), 8.42\left(\mathrm{~d}, 1 \mathrm{H}, \mathrm{CH}^{3} \mathrm{~J}_{\mathrm{HH}}=6.9 \mathrm{~Hz}\right) .{ }^{13} \mathrm{C}$ NMR (75 MHz) $\delta: 19.4\left(\mathrm{SCH}_{3}\right), 21.8\left(\mathrm{CH}_{3}\right), 56.9(\mathrm{CH}), 124.7(\mathrm{C}=\mathrm{C}), 133.7(\mathrm{C}=\mathrm{C}), 172.8$ $\left(\mathrm{C}^{+}\right.$-SMe). HRMS (ESI, QTOF 2) calcd for $\mathrm{C}_{7} \mathrm{H}_{12} \mathrm{NS}_{2}{ }^{+}$: 174.04112, found: 174.0410. Anal. calcd for $\mathrm{C}_{7} \mathrm{H}_{12} \mathrm{NS}_{2} \mathrm{I}$ : C, 27.90; H, 3.99; N, 4.65; S, 21.30. Found: C, 27.81; H, 4.20; N, 4.85; $\mathrm{S}, 21.48$. Sodium methanolate solution (1 $\mathrm{M}$ in $\mathrm{MeOH}, 9.4 \mathrm{~mL}, 9.4 \mathrm{mmol})$ was added under inert atmosphere to a solution of the thiazolium salt $(2.2 \mathrm{~g}, 7.3 \mathrm{mmol})$ in dry methanol (20 $\mathrm{mL}$ ). The reaction was stirred at room temperature for $5 \mathrm{~h}$, extracted with dichloromethane and washed with saturated $\mathrm{NaCl}$ solution. The concentrated solution was purified by column chromatography on silica gel using $\mathrm{CH}_{2} \mathrm{Cl}_{2} / \mathrm{Et}_{2} \mathrm{O}$ (9.9/0.1) as eluent and thiazoline-2-one 4 was isolated as yellow oil in $87 \%$ yield $(0.91 \mathrm{~g}) . \mathrm{R}_{\mathrm{f}}=0.35\left(\mathrm{SiO}_{2}, \mathrm{CH}_{2} \mathrm{Cl}_{2} / \mathrm{Et}_{2} \mathrm{O}, 9.9 / 0.1\right) .{ }^{1} \mathrm{H}$ 
NMR $(300 \mathrm{MHz}) \delta: 1.25\left(\mathrm{~d}, 6 \mathrm{H}, \mathrm{CH}_{3},{ }^{3} \mathrm{~J}_{\mathrm{HH}}=7.4 \mathrm{~Hz}\right), 4.48\left(\mathrm{sept}, 1 \mathrm{H}, \mathrm{CH},{ }^{3} \mathrm{~J}_{\mathrm{HH}}=7.4 \mathrm{~Hz}\right)$, $6.06\left(\mathrm{~d}, 1 \mathrm{H}, \mathrm{CH}^{3} \mathrm{~J}_{\mathrm{HH}}=6.9 \mathrm{~Hz}\right), 6.58\left(\mathrm{~d}, 1 \mathrm{H}, \mathrm{CH}^{3} \mathrm{~J}_{\mathrm{HH}}=6.9 \mathrm{~Hz}\right) .{ }^{13} \mathrm{C} \mathrm{NMR}(75 \mathrm{MHz}) \delta$ (ppm): $21.5\left(\mathrm{CH}_{3}\right), 45.9(\mathrm{CH}), 100.8(\mathrm{C}=\mathrm{C}), 120.6(\mathrm{C}=\mathrm{C}), 171.1(\mathrm{C}=\mathrm{O})$. HRMS (ASAP, QTOF 2) calcd for $\mathrm{C}_{6} \mathrm{H}_{10} \mathrm{NSO}^{+}:$144.04831, found: 144.0485 .

\section{Bis(4,5-cyanoethylthio)-1,3-thiazoline-2-one 5.}

Under inert atmosphere at $0^{\circ} \mathrm{C}, \mathrm{LDA}$ was prepared by adding $n \mathrm{BuLi}(3.9 \mathrm{~mL}, 6.30 \mathrm{mmol}, 1.6$ $\mathrm{M}$ in hexane) to a solution of diisopropylamine $(0.9 \mathrm{~mL}, 6.30 \mathrm{mmol})$ in $10 \mathrm{~mL}$ of anhydrous THF. The LDA solution was added to a solution of 1,3-thiazoline-2-one 4 (0.60 g, 4.20 mmol) in $40 \mathrm{~mL}$ of anhydrous THF at $-10^{\circ} \mathrm{C}$. After stirring for 30 minutes, sulfur $(0.20 \mathrm{~g}$, $6.30 \mathrm{mmol}$ ) was added to the reaction mixture, and the medium was stirred for an additional 30 minutes before the addition of LDA $(8.40 \mathrm{mmol}$ prepared from $5.3 \mathrm{~mL}$ of $n \mathrm{BuLi}, 1.6 \mathrm{M}$ in hexane, and $1.2 \mathrm{~mL}$ of diisopropylamine in $15 \mathrm{~mL}$ of anhydrous THF). The reaction mixture was stirred for 3 hours, and sulfur was added $(0.27 \mathrm{~g}, 8.40 \mathrm{mmol})$, followed $30 \mathrm{~min}$ later by the addition of 3-bromopropionitrile $(3.5 \mathrm{~mL}, 41.9 \mathrm{mmol})$. The temperature was allowed to rise to room temperature and then the reaction was stirred overnight. Tetrahydrofuran was evaporated and the residue was extracted with dichloromethane. The organic phase was washed with water and dried over $\mathrm{MgSO}_{4}$. The resulting oil was purified by column chromatography on silica gel using $\mathrm{CH}_{2} \mathrm{Cl}_{2} / \mathrm{Et}_{2} \mathrm{O}(9.8 / 0.2)$ as eluent. Compound 5 was isolated as brown orange oil in $36 \%$ yield $(0.26 \mathrm{~g}) . \mathrm{R}_{f}=0.27\left(\mathrm{SiO}_{2}, \mathrm{CH}_{2} \mathrm{Cl}_{2} / \mathrm{Et}_{2} \mathrm{O}, 9.8 / 0.2\right) .{ }^{1} \mathrm{H}$ NMR $(300 \mathrm{MHz}) \delta: 1.54\left(\mathrm{~d}, 6 \mathrm{H}, \mathrm{CH}_{3},{ }^{3} \mathrm{~J}_{\mathrm{HH}}=6.9 \mathrm{~Hz}\right), 2.72\left(\mathrm{t}, 4 \mathrm{H}, \mathrm{CH}_{2},{ }^{3} \mathrm{~J}_{\mathrm{HH}}=6.9 \mathrm{~Hz}\right), 3.04$ $\left(\mathrm{t}, 4 \mathrm{H}, \mathrm{CH}_{2},{ }^{3} \mathrm{~J}_{\mathrm{HH}}=6.9 \mathrm{~Hz}\right), 4.77\left(\mathrm{sept}, 1 \mathrm{H}, \mathrm{CH},{ }^{3} \mathrm{~J}_{\mathrm{HH}}=6.9 \mathrm{~Hz}\right) .{ }^{13} \mathrm{C} \mathrm{NMR}(75 \mathrm{MHz}) \delta: 18.2$

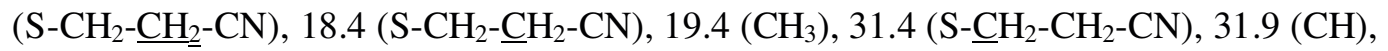
$116.7(\mathrm{CN}), 117.2(\mathrm{C}=\mathrm{C}), 131.1(\mathrm{C}=\mathrm{C}), 169.1(\mathrm{C}=\mathrm{O})$. HRMS (ESI, QTOF 2) calcd for $\mathrm{C}_{12} \mathrm{H}_{15} \mathrm{~N}_{3} \mathrm{ONaS}_{3}^{+}: 336.0275$, found: 336.0272 . 
$\left[\mathbf{P P h}_{4}\right]\left[\mathbf{A u}(i \mathbf{P r}-\text { thiazYdt })_{2}\right](\mathbf{Y}=\mathbf{O}, \mathbf{S e})$. To a dry two-neck flask containing 1,3-thiazoline2-selone 3 ( $0.30 \mathrm{~g}, 0.80 \mathrm{mmol})$ or 1,3-thiazoline-2-one $5(0.15 \mathrm{~g}, 0.87 \mathrm{mmol})$ a solution of sodium methalonate $1 \mathrm{M}$ in $\mathrm{MeOH}$ was added $(8.7 \mathrm{~mL}$ for 5 and $6 \mathrm{~mL}$ for 3$)$ under argon atmosphere at room temperature. After stirring for $30 \mathrm{~min}$, a solution of potassium tetrachloroaurate (III) hydrate $\left(\mathrm{KAuCl}_{4} \cdot \mathrm{H}_{2} \mathrm{O}\right)(\mathbf{3}: 0.18 \mathrm{~g}, 0.48 \mathrm{mmol} ; \mathbf{5}: 0.20 \mathrm{~g}, 0.52 \mathrm{mmol})$ in $7 \mathrm{~mL}$ of anhydrous methanol was added to the reaction mixture followed, $5 \mathrm{~h}$ later, by the addition of tetraphenylphosphonium chloride $\left(\mathrm{PPh}_{4} \mathrm{Cl}\right)($ 3: $0.18 \mathrm{~g}, 0.48 \mathrm{mmol}$, 5: $0.20 \mathrm{~g}, 0.52$ $\mathrm{mmol}$ ) in $7 \mathrm{~mL}$ of anhydrous methanol. Then the reaction was stirred overnight at room temperature under argon atmosphere. The dark brown solution was filtered and concentrated in vacuo. The resulting solid was washed with $\mathrm{MeOH}$ and recrystallized from acetonitrile. [PPh 4 ] $\left.\mathbf{A u}(\boldsymbol{i P r} \text {-thiazSedt })_{2}\right], \mathrm{C}_{36} \mathrm{H}_{34} \mathrm{AuN}_{2} \mathrm{PS}_{8}$; black green crystals. Yield: $0.22 \mathrm{~g}(52 \%)$; mp $=180{ }^{\circ} \mathrm{C} .{ }^{1} \mathrm{H}$ NMR $(300 \mathrm{MHz})$ at room temperature $\delta 1.58$ (broad signal, $12 \mathrm{H}, \mathrm{CH}_{3},{ }^{3} \mathrm{~J}_{\mathrm{HH}}=$ $7.1 \mathrm{~Hz}), 5.78\left(\right.$ broad signal, 2H, $\left.\mathrm{CH},{ }^{3} \mathrm{~J}_{\mathrm{HH}}=7.0 \mathrm{~Hz}\right), 7.63\left(\mathrm{~m}, 8 \mathrm{H}, \mathrm{CH}_{\mathrm{Ar}}\right), 7.78\left(\mathrm{~m}, 8 \mathrm{H}, \mathrm{CH}_{\mathrm{Ar}}\right)$, 7.93 (m, 4H, $\mathrm{CH}_{\mathrm{Ar}}$ ). Anal. calcd for $\mathrm{C}_{36} \mathrm{H}_{34} \mathrm{AuN}_{2} \mathrm{PS}_{8}: \mathrm{C}, 40.30 ; \mathrm{H}, 3.19 ; \mathrm{N}, 2.61$. Found: $\mathrm{C}$, $40.24 ; \mathrm{H}, 3.46 ; \mathrm{N}, 2.98$.

[PPh 4$]\left[\mathbf{A u}(\text { iPr-thiazOdt })_{2}\right], \mathrm{C}_{36} \mathrm{H}_{34} \mathrm{AuN}_{2} \mathrm{PO}_{2} \mathrm{~S}_{6}$; black green crystals. Yield: $0.14 \mathrm{~g}(34 \%)$; $\mathrm{mp}=184{ }^{\circ} \mathrm{C} .{ }^{1} \mathrm{H} \mathrm{NMR}(300 \mathrm{MHz})$ at room temperature $\delta 1.45\left(\mathrm{~d}, 6 \mathrm{H}, \mathrm{CH}_{3},{ }^{3} \mathrm{~J}_{\mathrm{HH}}=7.1 \mathrm{~Hz}\right)$, $1.49\left(\mathrm{~d}, 6 \mathrm{H}, \mathrm{CH}_{3},{ }^{3} \mathrm{~J}_{\mathrm{HH}}=7.1 \mathrm{~Hz}\right), 4.45\left(\mathrm{sept}, 2 \mathrm{H}, \mathrm{CH},{ }^{3} \mathrm{~J}_{\mathrm{HH}}=7.0 \mathrm{~Hz}\right), 4.46\left(\right.$ sept, $2 \mathrm{H}, \mathrm{CH},{ }^{3} \mathrm{~J}_{\mathrm{HH}}$ $=7.0 \mathrm{~Hz}), 7.59\left(\mathrm{~m}, 8 \mathrm{H}, \mathrm{CH}_{\mathrm{Ar}}\right), 7.73\left(\mathrm{~m}, 8 \mathrm{H}, \mathrm{CH}_{\mathrm{Ar}}\right), 7.87\left(\mathrm{~m}, 4 \mathrm{H}, \mathrm{CH}_{\mathrm{Ar}}\right) .{ }^{13} \mathrm{C} \mathrm{NMR}(75 \mathrm{MHz})$ $\delta: 20.2\left(\mathrm{~N}-\mathrm{C}\left(\underline{\mathrm{C}}_{3}\right)_{3}\right), 49.7\left(\mathrm{~N}-\underline{\mathrm{C}}\left(\mathrm{CH}_{3}\right)_{3}\right), 100.7(\mathrm{C}=\mathrm{C}), 117.0\left(\mathrm{C}_{\mathrm{Ar}}\right), 118.2\left(\mathrm{C}_{\mathrm{Ar}}\right), 123.5(\mathrm{C}=\mathrm{C})$, $130.8\left(\mathrm{C}_{\mathrm{Ar}}\right), 134.5\left(\mathrm{C}_{\mathrm{Ar}}\right), 135.9\left(\mathrm{C}_{\mathrm{Ar}}\right), 177.4(\mathrm{C}=\mathrm{O}) . \mathrm{UV}$-vis-NIR $\left(\mathrm{CH}_{2} \mathrm{Cl}_{2}\right) \lambda(\mathrm{nm}), \varepsilon\left(\mathrm{M}^{-1} \cdot \mathrm{cm}^{-}\right.$ $\left.{ }^{1}\right): 310,33480 ; 260,49520 ; 232,70948$. HRMS (ESI, Q-Exactive) calcd for $\mathrm{C}_{12} \mathrm{H}_{14} \mathrm{~N}_{2} \mathrm{O}_{2} \mathrm{~S}_{6} \mathrm{Au}^{-}$ : 606.90507, found: 606.9051. Anal. calcd for $\mathrm{C}_{36} \mathrm{H}_{34} \mathrm{AuN}_{2} \mathrm{PO}_{2} \mathrm{~S}_{6}: \mathrm{C}, 45.66 ; \mathrm{H}, 3.62 ; \mathrm{N}$, 2.99. Found: C, $45.74 ; \mathrm{H}, 3.51 ; \mathrm{N}, 2.66$. 


\subsection{X-ray crystallography}

Single crystal diffraction data were collected on a D8 VENTURE Bruker AXS diffractometer for complex $\left[\mathrm{PPh}_{4}\right]\left[\mathrm{Au}(i \mathrm{Pr} \text {-thiazOdt })_{2}\right]$ and on an APEXII Bruker AXS diffractometer for complex $\left[\mathrm{PPh}_{4}\right]\left[\mathrm{Au}(i \mathrm{Pr}-\text { thiazSedt })_{2}\right]$, ( Mo-K $\alpha$ radiation, $\lambda=0.71073 \AA$ ). The structures were solved by direct methods using the SIR97 program [20], and then refined with full-matrix least-square methods based on $F^{2}$ (SHELXL-97) [21]. All non-hydrogen atoms were refined with anisotropic atomic displacement parameters. $\mathrm{H}$ atoms were finally included in their calculated positions. The squeeze procedure implemented in PLATON [22] was used for $\left[\mathrm{PPh}_{4}\right]\left[\mathrm{Au}(i \mathrm{Pr}-\text { thiazSedt })_{2}\right]$ structure refinement. Crystallographic data on X-ray data collection and structure refinements are given in Table 6 for both complexes. 
Table 6 Crystallographic data

\begin{tabular}{lll}
\hline Compound & {$\left[\mathrm{PPh}_{4}\right]\left[\mathrm{Au}(i \mathrm{Pr}-\mathrm{thiazSedt})_{2}\right]$} & {$\left[\mathrm{PPh}_{4}\right]\left[\mathrm{Au}(i \mathrm{Pr}-\mathrm{thiazOdt})_{2}\right]$} \\
\hline Formula & $\mathrm{C} 36 \mathrm{H} 34 \mathrm{AuN} 2 \mathrm{PS} 6 \mathrm{Se} 2$ & $\mathrm{C}_{36} \mathrm{H}_{34} \mathrm{AuN}_{2} \mathrm{O}_{2} \mathrm{PS}_{6}, 2\left(\mathrm{CH}_{3} \mathrm{CN}\right)$ \\
$\mathrm{FW}\left(\mathrm{g} \cdot \mathrm{mol}^{-1}\right)$ & 1072.87 & 1029.05 \\
Crystal system & monoclinic & monoclinic \\
Space group & $\mathrm{C} 2 / \mathrm{c}$ & $\mathrm{C} 2 / \mathrm{c}$ \\
$a(\AA)$ & $29.179(5)$ & $25.5832(13)$ \\
$b(\AA)$ & $7.3992(11)$ & $7.4698(3)$ \\
$c(\AA)$ & $22.332(4)$ & $24.6357(11)$ \\
$\alpha\left(^{\circ}\right)$ & 90 & \\
$\beta\left({ }^{\circ}\right)$ & $125.699(5)$ & 90 \\
$\gamma\left({ }^{\circ}\right)$ & 90 & $116.7190(10)$ \\
$V\left(\AA^{3}\right)$ & $3915.5(11)$ & 90 \\
$T(\mathrm{~K})$ & $150(2)$ & $4205.2(3)$ \\
$Z$ & 4 & $150(2)$ \\
$D_{\text {calc }}\left(\mathrm{g} \cdot \mathrm{cm}{ }^{-3}\right)$ & 1.820 & 4 \\
$\mu\left(\mathrm{mm}{ }^{-1}\right)$ & 6.007 & 1.625 \\
Total refls. & 16979 & 3.874 \\
Uniq. refls. $\left(R_{\text {int }}\right)$ & $4514(0.0344)$ & 27773 \\
Unique refls. $(\mathrm{I}>2 \mathrm{~s}(\mathrm{I}))$ & 3751 & $4855(0.0506)$ \\
$R_{1}, w R_{2}$ & $0.0359,0.0947$ & 4098 \\
$R_{1}, w R_{2}($ all data $)$ & $0.0452,0.0999$ & $0.0285,0.0520$ \\
GoF & 1.029 & $0.0394,0.0548$ \\
\hline & & 1.085 \\
\hline
\end{tabular}

4.4. Computational Details.

Full geometry optimization with Density Functional Theory [23] calculations were performed with the hybrid Becke-3 parameter exchange functional [24] and the Lee-Yang-Parr non local 
correlation functional [25] (B3LYP) implemented in the Gaussian 03 (revision D.02) program suite [26] using the 6-31G* basis set [27] and the LANL2DZ basis set [28].

\section{Acknowledgement}

This work was granted access to the high performance computing resources of CINES (Montpellier, France) under the allocation 2017-A0020805032 awarded by GENCI. Financial support was obtained from ANR (Paris, France) under contract n 12-BS07-0032-01.

\section{Appendix A. Supplementary data}

CCDC 1547966-1547967 contains the supplementary crystallographic data for $\left[\mathrm{PPh}_{4}\right][\mathrm{Au}(i \mathrm{Pr}-$ thiazSedt $\left.)_{2}\right]$ and $\left[\mathrm{PPh}_{4}\right]\left[\mathrm{Au}(i \mathrm{Pr} \text {-thiazOdt })_{2}\right]$ respectively. These data can be obtained free of charge via http://www.ccdc.cam.ac.uk/conts/retrieving.html, or from the Cambridge Crystallographic Data Centre, 12 Union Road, Cambridge CB2 1EZ, UK; fax: (+44) 1223336-033; or e-mail: deposit@ccdc.cam.ac.uk.

\section{References}

[1] (a) P. Batail, P. (Ed.), Special issue on Molecular Conductors, Chem. Rev. 104 (2004) $4887-5781$.

(b) N. Martin, Chem. Commun. 49 (2013) 7025-7027.

[2] (a) Y. Okano, B. Zhou, H. Tanaka, T. Adachi, Y. Ohishi, M. Takata, S. Aoyagi, E. Nishibori, M. Sakata, A. Kobayashi, H. Kobayashi, J. Am. Chem. Soc. 131 (2009) 71697174. 
(b) B. Zhou, M. Shimamura, E. Fujiwara, A. Kobayashi, T. Higashi, E. Nishibori, M. Sakata, H. Cui, K. Takahashi, H. Kobayashi, J. Am. Chem. Soc. 128 (2006) 3872-3873.

(c) W.Suzuki, E. Fujiwara, A. Kobayashi, Y. Fujishiro, E. Nishibori, M. Takata, M. Sakata, H. Fujiwara, H. Kobayashi, J. Am. Chem. Soc. 125 (2003) 1486-1487.

[3] (a) N. C. Schiødt, T. Bjørnholm, K. Bechgaard, J. J. Neumeier, C. Allgeier, C. S. Jacobsen, N. Thorup, Phys. Rev. B 53(1996) 1773-1778;

(b) D. Belo, H. Alves, E. B. Lopes, M. T. Duarte, V. Gama, R. T. Henriques, M. Almeida, A. Pérez-Benítez, C. Rovira, J. Veciana, Chem. Eur. J. 7( 2001) 511-519;

(c) O. J. Dautel, M. Fourmigué, E. Canadell, P. Auban-Senzier, Adv. Funct. Mater. 12 (2002) 693-698;

(d) R. Le Pennec, O. Jeannin, P. Auban-Senzier, M. Fourmigué, New J. Chem. 40 (2016) 7113-7120.

[4] (a) N. Tenn, N. Bellec, O. Jeannin, L. Piekara-Sady, P. Auban-Senzier, J. Íñiguez, E. Canadell, D. Lorcy, J. Am. Chem. Soc. 131 (2009) 16961-16967;

(b) G. Yzambart, N. Bellec, G. Nasser, O. Jeannin, T. Roisnel, M. Fourmigué, P. AubanSenzier, J. Íniguez, E. Canadell, D. Lorcy, J. Am. Chem. Soc. 134 (2012) 17138-17148;

(c) Y. Le Gal, T. Roisnel, P. Auban-Senzier, T. Guizouarn, D. Lorcy, Inorg. Chem. 53 (2014) $8755-8761$.

[5] A. Filatre-Furcate, O. Jeannin, P. Auban-Senzier, M. Fourmigué, J. Íñiguez, E. Canadell, B. Brière, V. Ta Phuoc, D. Lorcy, Inorg. Chem. 55 (2016) 6036-6046.

[6] C. Roussel, R. Gallo, M. Chanon, J. Metzger, J. Chem. Soc. Perkin II (1974) 1304-1306. 
[7] C. Roussel, A. Lidén, M. Chanon, J. Metzger, J. Sandström, J. Am. Chem. Soc. 98 (1976) 2847-2852.

[8] (a) C. Roussel, M. Chanon, J. Metzger, Tetrahedron Lett. 21 (1971) 1861-1864;

(b) A. Lidén, C. Roussel, T. Liljefors, M. Chanon, R. E. Carter, J. Metzger, J. Sandström, J. Am. Chem. Soc. 98 (1976) 2853-2860.

[9] C. M. Roussel, R. Gallo, M. Chanon, J. Metzger, Bull. Soc. Chim. Fr. (1971) 1902-1907.

[10] (a) N. Bellec, D. Lorcy, A. Robert, R. Carlier, A. Tallec, C. Rimbaud, L. Ouahab, R. Clérac, P. Delhaes, Adv. Mater. 9 (1997) 1052-1056;

(b) N. Bellec, D. Lorcy, A. Robert, Synthesis (1998) 1442-1446.

[11] (a) J. Rochester, U. Berg, M. Pierrot, J. Sandström, J. Am. Chem. Soc. 109 (1987) 492507

(b) U. Berg, T. Liljefors, C. Roussel, J. Sandström, Acc. Chem. Res. 18 (1985) 80-86.

[12] A. Filatre-Furcate, T. Roisnel, D. Lorcy, J. Organomet. Chem. 819 (2016) 182-188.

[13] (a) S. Rabaca, A. C. Cerdeira, S. Oliveira, I. C. Santos, R. T. Henriques, L. C. J. Pereira, J. T. Coutinho, M. Almeida, Polyhedron 39 (2012) 91-98;

(b) E. Laukhina, V. Lebedev, V. Laukhin, A. P. del Pino, E. B. Lopes, A. I. S. Neves, D. Belo, M. Almeida, J. Veciana, C. Rovira, Org. Electron. 13 (2012) 894-898;

(c) D. Belo, H. Alves, E. B. Lopes, M. T. Duarte, V. Gama, R. T. Henriques, M. Almeida, A. Pérez-Benítez, C. Rovira, J. Veciana, Chem. Eur. J. 7 (2001) 511-519.

[14] (a) A. Filatre-Furcate, P. Auban-Senzier, M. Fourmigué, T. Roisnel, V. Dorcet, D. Lorcy, Dalton Trans. 44 (2015) 15683-15689; 
(b) T. Higashino, O. Jeannin, T. Kawamoto, D. Lorcy, T. Mori, M. Fourmigué, Inorg. Chem. 54 (2015) 9908-9913;

[15] (a) L. Ambrosio, M. C. Aragoni, M. Arca, F. A. Devillanova, M. B. Hursthouse, S. L. Huth, F. Isaia, V. Lippolis, A. Mancini, A. Pintus, Chem. Asian J. 5 (2010) 1395-1406;

(b) J. M. Tunney, A. J. Blake, E. S. Davies, J. McMaster, C. Wilson, C. D. Garner, Polyhedron 25 (2006) 591-598.

[16] R.-M. Olk, W. Dietzsch, K. Köhler, R. Kirmse, J. Reinold, E. Hoyer, L. Golič, B. Olk, Z. Anorg. Allg. Chem. 567 (1988)131-144.

[17] S. G. Liu, Y. Q. Liu, Y. F. Li, D. B. Zhu, Synth. Met. 114 (2000) 139-146

[18] (a) S. R. Kennedy, M. N. Kozar, H. P. Yennawar, B. J. Lear, Polyhedron 103 (2016) 100104

(b) X. Ribas, J. Dias, J. Morgado, K. Wurst, E. Molins, E. Ruiz, M. Almeida, J. Veciana,

C. Rovira, Chem. Eur. J. 10 (2004) 1691-1704;

(c) G. Bruno, M. Almeida, D. Simão, M. Mercuri, L. Pilia, A. Serpe, P. Deplano, Dalton Trans. 3 (2009) 495-503;

(d) M. Aragoni, M. Arca, F. Devillanova, F. Isaia, V. Lippolis, A. Pintus, Chem. Asian J. 6 (2011) 198-208.

[19] (a) K. Ray, T. Weyhermüller, A. Goossens, M.W.J. Crajé, K. Wieghardt, Inorg. Chem. 42 (2003) 4082-4087;

(b) N. C. Schiødt, P. Sommer-Larsen, T. Bjørnholm, M. Folmer Nielsen, J. Larsen, K. Bechgaard, Inorg. Chem. 34 (1995) 3688-3694. 
[20] A. Altomare, M. C. Burla, M. Camalli, G. Cascarano, C. Giacovazzo, A. Guagliardi, A. G. G. Moliterni, G. Polidori, R. Spagna, J. Appl. Cryst. 32 (1999) 115-119.

[21] G.M. Sheldrick, Acta Cryst. A64 (2008), 112-122.

[22] A. L. Spek, Acta. Cryst. D65 (2009) 148-155.

[23] (a) P. Hohenberg, W. Kohn, Phys. Rev. 136 (1964) B864-B871;

(b) R. G. Parr, W. Yang, Density-Functional Theory of Atoms and Molecules; Oxford University Press: Oxford, U.K., 1989.

[24] (a) A. D. Becke, Phys. Rev. A 38 (1988) 3098-3100;

(b) A. D. Becke, J. Chem. Phys. 98 (1993) 1372-1377;

(c) A. D. Becke, J. Chem. Phys.98 (1993) 5648-5652.

[25] C. Lee, W. Yang, R. G. Parr, Phys. Rev. B 37 (1988) 785 - 789.

[26] Gaussian 03, Revision D.02, M. J. Frisch, G. W. Trucks, H. B. Schlegel, G. E. Scuseria, M. A. Robb, J. R. Cheeseman, J. A. Montgomery, Jr., T. Vreven, K. N. Kudin, J. C. Burant, J. M. Millam, S. S. Iyengar, J. Tomasi, V. Barone, B. Mennucci, M. Cossi, G. Scalmani, N. Rega, G. A. Petersson, H. Nakatsuji, M. Hada, M. Ehara, K. Toyota, R. Fukuda, J. Hasegawa, M. Ishida, T. Nakajima, Y. Honda, O. Kitao, H. Nakai, M. Klene, X. Li, J. E. Knox, H. P. Hratchian, J. B. Cross, V. Bakken, C. Adamo, J. Jaramillo, R. Gomperts, R. E. Stratmann, O. Yazyev, A. J. Austin, R. Cammi, C. Pomelli, J. W. Ochterski, P. Y. Ayala, K. Morokuma, G. A. Voth, P. Salvador, J. J. Dannenberg, V. G. Zakrzewski, S. Dapprich, A. D. Daniels, M. C. Strain, O. Farkas, D. K. Malick, A. D. Rabuck, K. Raghavachari, J. B. Foresman, J. V. Ortiz, Q. Cui, A. G. Baboul, S. Clifford, J. Cioslowski, B. B. Stefanov, G. Liu, A. Liashenko, P. Piskorz, I. Komaromi, R. L. Martin, D. J. Fox, T. Keith, M. A. Al-Laham, C. Y. Peng, A. Nanayakkara, M. 
Challacombe, P. M. W. Gill, B. Johnson, W. Chen, M. W. Wong, C. Gonzalez, and J. A. Pople, Gaussian, Inc., Wallingford CT, 2004.

[27] P. C. Hariharan, J. A. Pople, Chem. Phys. Lett. 16 (1972) 217-219.

[28] (a) Wadt, W. R.; Hay, P. J. J. Chem. Phys. 82 (1985) 284-298;

(b) P. J. Hay, W. R. Wadt, J. Chem. Phys. 82 (1985) 299-310. 


\section{Graphical Abstract}

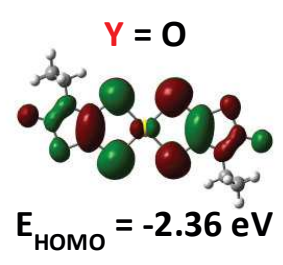

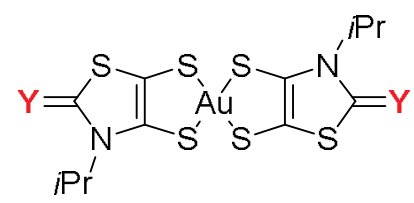

[Au(Pr-thiazYdt) $\left.)_{2}\right]$ $Y=0, S$, Se

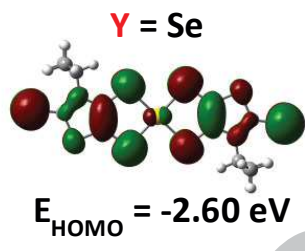




\section{Highlights}

Influence of the exocyclic chalcogen atoms of the ligands on the properties of gold dithiolene complexes.

Influence of the size, electronegativity and polarizability of the exocyclic chalcogen atom. Conformational equilibrium between rotamers.

Exocyclic oxygen atoms increases the potential domain of stability of the neutral species. 